\title{
Clinical assessment of bronchodilator drugs delivered by aerosol
}

\author{
GILLIAN M. SHENFIELD and J. W. PATERSON \\ Asthma Research Council Clinical Pharmacology Unit, Department of Medicine, \\ Institute of Diseases of the Chest, Brompton, London S.W.3
}

\begin{abstract}
A method is described for the early clinical evaluation of bronchodilator aerosols. It is simple to perform, and an accurate estimate of potency can be obtained in a small number of patients. Using this method, three new sympathomimetic drugs, Th 1165a, salmefamol, and rimiterol, have been tested. All proved to be active bronchodilators and were equipotent with isoprenaline or salbutamol.
\end{abstract}

The assessment of bronchodilator drugs poses several problems. The natural variability of asthma and of patient response from day to day cause considerable difficulty (Hume and Gandevia, 1957 ; Hume and Rhys Jones, 1961). Even when initial measurements are the same on different days, the patient's response will depend on whether he is improving or getting worse at the time (Pain and Read, 1963). Further problems arise when considering what measurements to make and how to express the results. These difficulties have recently been summarized by Alliott, Lang, Rawson, and Leckie (1972).

We have developed a simple and reproducible method for assessing new aerosol bronchodilator drugs, which overcomes many of the difficulties and provides useful additional information even with only a small number of patients. We describe here the results obtained with three new sympathomimetic drugs, Th 1165a, salmefamol, and rimiterol, using this method.

\section{PATIENTS AND METHODS}

There were three separate studies: (1) a comparison between $T h 1165 \mathrm{a}^{1}$ and salbutamol ${ }^{2}$; (2) a comparison between salmefamol ${ }^{3}$ and isoprenaline; and (3) a comparison between rimiterol ${ }^{4}$ and isoprenaline (Table I). The first trial was done as a pilot study

11 - (3, 5 - dihydroxy - phenyl) - 2 - ( (1 - (4 - hydroxy - benzyl) ethyl)-amino)-ethanol-hydrobromide

$22-t$ - butvlamino - 1 - (4-hydroxy - 3 - hydroxymethyl) - phenyl -

3 Paramethroxyphenyl - 1 - isopropylamino - 1 (4 - hydroxy - 3 hydroxymethyl) phenylethanol

4 Erythro - 2 - piperidinemethanol, 2 - (3, 4 - dihydroxyphenyl) hydrobromide
T A B LE I

CONTENT OF ADRENERGIC DRUG IN EACH AEROSOL

\begin{tabular}{|c|c|c|c|c|c|}
\hline Drug & $\begin{array}{c}\text { Molecular } \\
\text { Weight }\end{array}$ & $\begin{array}{l}\text { Chemical } \\
\text { Form in } \\
\text { Aerosol }\end{array}$ & $\begin{array}{l}\text { Dose } \\
\text { in } \\
1 \text { Puff } \\
(\mu \mathrm{g})\end{array}$ & $\begin{array}{c}\text { Dose of } \\
\text { of Free } \\
\text { Base in } \\
1 \text { Puff } \\
(\mu \mathrm{g})\end{array}$ & $\begin{array}{c}\mu \text { moles } \\
\text { in } \\
1 \text { Puff }\end{array}$ \\
\hline $\begin{array}{l}\text { Isoprenaline } \\
\text { Salbutamol } \\
\text { Th 1165a } \\
\text { Salmefamol } \\
\text { Rimiterol }\end{array}$ & $\begin{array}{l}211 \\
239 \\
303 \\
331 \\
223\end{array}$ & $\begin{array}{c}\text { Sulphate } \\
\text { Free base } \\
\text { Hydrobromide } \\
\text { Free base } \\
\text { Hydrobromide }\end{array}$ & $\begin{array}{r}100 \\
100 \\
200 \\
50 \\
110\end{array}$ & $\begin{array}{r}76 \\
100 \\
160 \\
50 \\
81\end{array}$ & $\begin{array}{l}0 \cdot 38 \\
0 \cdot 4 \\
0 \cdot 5 \\
0 \cdot 15 \\
0 \cdot 36\end{array}$ \\
\hline
\end{tabular}

and after its results had been studied the protocol was modified for the subsequent two trials.

All patients were in hospital with exacerbations of airways obstruction. All were known to be capable of responding to an aerosol-administered bronchodilator and improving their forced expiratory volume in 1 second $\left(F E V_{1}\right)$ by at least $20 \%$. Patients in the second and third studies were further selected as having an FEV $_{1}$ of $70 \%$ or less than their predicted normal values. All had previously used pressurized aerosols and knew how to use the dry spirometer (Vitalograph).

Measurements were made in the mornings of two days, all bronchodilator drugs having been stopped from 10 p.m. on the night preceding the study. Measurements were made of pulse rate, blood 0 pressure, FEV $_{1}$ and forced vital capacity (FVC); the best of three readings was taken for FEV 1 and FVC (in some patients repeated spirometry produced deterioration, and in these cases only one estimation was performed each time). The procedure was identical on the two study days, but on the second day the pre-treatment $\mathrm{FEV}_{1}$ had to be within $15 \%$ of that on the first day for the study to continue.

The patient inhaled one puff from the chosen 
aerosol and at 5-minute intervals after this all measurements were repeated until the $\mathrm{FEV}_{1}$ showed no further rise. A second puff was then taken from the aerosol and measurements were made as before. Third and fourth puffs were taken and in the second two studies a further two puffs after this. In this way the cumulative dose taken was one, two, and four puffs in the first study, and one, two, four, and six puffs in the other two studies.

The same observer always studied any individual patient on both days, and in the second and third studies the trial was double-blind with the aerosols given in random order.

\section{RESULTS}

Pulse and blood pressure did not change significantly in any of the studies, and there were no side effects other than slight tremor after salmefamol (see below). All $\mathrm{FEV}_{1}$ results were assessed on the assumption that the time intervals between puffs were so short that the effect was produced by a cumulative dose. The values given for $\mathrm{FEV}_{1}$ were the best recorded at each dose of aerosol, and before the next puff was taken.

STUDY 1: Th 1165a $v$ SALBUTAMOL Table II shows the results for eight patients. In each case

T A B L E I I

DETAILS OF PATIENTS AND THEIR FEV 1 RESULTS IN STUDY 1

\begin{tabular}{|c|c|c|c|c|c|c|}
\hline \multirow{2}{*}{ Patient } & \multirow{2}{*}{ Drug } & \multicolumn{5}{|c|}{$\mathrm{FEV}_{1}$ (1.) } \\
\hline & & Predicted & Baseline & 1 Puff & 2 Puffs & 4 Puffs \\
\hline $\begin{array}{l}\text { P.F. } \\
\text { S.H. } \\
\text { P.D. } \\
\text { E.R. } \\
\text { G.B. } \\
\text { M.E. } \\
\text { S.F. } \\
\text { S.B. }\end{array}$ & $\begin{array}{l}\text { Th 1165a } \\
\text { Salbutamol } \\
\text { Th 1165a } \\
\text { Salbutamol } \\
\text { Th 1165a } \\
\text { Salbutamol } \\
\text { Th 1165a } \\
\text { Salbutamol } \\
\text { Th 1165a } \\
\text { Salbutamol } \\
\text { Th 1165a } \\
\text { Salbutamol } \\
\text { Th 1165a } \\
\text { Salbutamol } \\
\text { Th 1165a } \\
\text { Salbutamol }\end{array}$ & $\begin{array}{l}3 \cdot 9 \\
3 \cdot 9 \\
4 \cdot 0 \\
4 \cdot 0 \\
3 \cdot 0 \\
3 \cdot 0 \\
2 \cdot 4 \\
2 \cdot 4 \\
4 \cdot 2 \\
4 \cdot 2 \\
3 \cdot 0 \\
3 \cdot 0 \\
2 \cdot 45 \\
2 \cdot 45 \\
2 \cdot 1 \\
2 \cdot 1\end{array}$ & $\begin{array}{l}1.5 \\
1.6 \\
3.7 \\
3.6 \\
0.7 \\
0.8 \\
1.6 \\
1.5 \\
1 \cdot 8 \\
1 \cdot 75 \\
1 \cdot 7 \\
1 \cdot 55 \\
1 \cdot 1 \\
1 \cdot 6 \\
1.0 \\
1 \cdot 25\end{array}$ & $\begin{array}{l}2 \cdot 15 \\
1.9 \\
4 \cdot 25 \\
4 \cdot 25 \\
1.0 \\
0.8 \\
1.9 \\
1 \cdot 75 \\
2 \cdot 5 \\
2 \cdot 5 \\
2 \cdot 3 \\
2 \cdot 25 \\
1.4 \\
1 \cdot 75 \\
1.4 \\
1 \cdot 7\end{array}$ & $\begin{array}{l}2 \cdot 4 \\
2 \cdot 0 \\
4 \cdot 2 \\
4 \cdot 25 \\
0.95 \\
1.0 \\
2 \cdot 05 \\
1.95 \\
2 \cdot 65 \\
2.65 \\
2.45 \\
2.35 \\
1.5 \\
1.9 \\
1.8 \\
1.8\end{array}$ & $\begin{array}{l}2 \cdot 55 \\
2 \cdot 15 \\
4 \cdot 35 \\
4 \cdot 25 \\
1 \cdot 1 \\
1 \cdot 0 \\
2 \cdot 1 \\
2 \cdot 0 \\
2 \cdot 65 \\
2 \cdot 7 \\
2 \cdot 6 \\
2 \cdot 5 \\
1 \cdot 5 \\
1 \cdot 9 \\
1 \cdot 9 \\
1 \cdot 85\end{array}$ \\
\hline
\end{tabular}

the predicted and baseline $\mathrm{FEV}_{1}$ values are shown, together with the value recorded after each dose of the drug. The results from two patients were unsatisfactory: patient S.H. showed little response to either drug but was very near his predicted $\mathrm{FEV}_{1}$ and so had little margin for improvement. Patient S.F. had baseline values not considered near enough to be comparable in the subsequent studies (i.e., more than $15 \%$ variation). For these reasons these two sets of results were rejected from further analysis. Figure 1 shows the mean results for six patients plotted as a log doseresponse curve, with a cumulative dose in puffs and the increase in $\mathrm{FEV}_{1}$ expressed as a percentage of the baseline value. The increase in FEV was slightly greater after $T h 1165 a$ but the difference was not statistically significant, and one puff of Th $1165 \mathrm{a}$ contained $0.5 \mu \mathrm{M}$ whereas one puff of salbutamol contained $0.4 \mu \mathrm{M}$ (Table I).

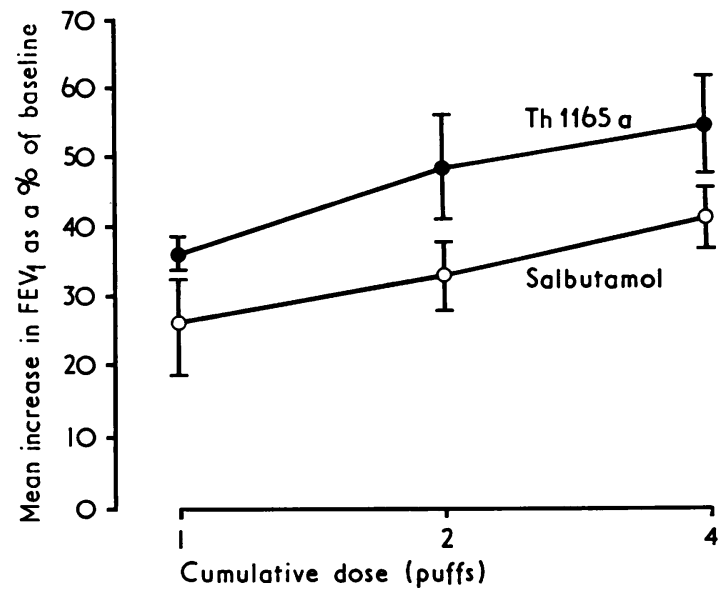

FIG. 1. Comparison of Th 1165 a and salbutamol, 6 patients.

STUDY 2: SALMEFAMOL $v$ ISOPRENALINE One patient had slight tremor after four and six puffs of salmefamol, but not after isoprenaline. No other side effects were noted, but one patient correctly identified isoprenaline by its taste.

T A B L E I I I

DETAILS OF PATIENTS AND THEIR FEV 1 RESULTS IN STUDY 2

\begin{tabular}{|c|c|c|c|c|c|c|c|}
\hline \multirow{2}{*}{ Patient } & \multirow{2}{*}{ Drug } & \multicolumn{6}{|c|}{$\mathrm{FEV}_{1}$ (1.) } \\
\hline & & Predicted & 1 Baseline & Puff & $\begin{array}{c}2 \\
\text { Puffs }\end{array}$ & $\begin{array}{c}4 \\
\text { Puffs }\end{array}$ & $\begin{array}{c}6 \\
\text { Puffs }\end{array}$ \\
\hline $\begin{array}{l}\text { C.V. } \\
\text { M.E. } \\
\text { J.z. } \\
\text { V.J. } \\
\text { A.D. } \\
\text { G.D. } \\
\text { R.G. } \\
\text { J.F. }\end{array}$ & $\begin{array}{l}\text { Salmefamol } \\
\text { Isoprenaline } \\
\text { Salmefamol } \\
\text { Isoprenaline } \\
\text { Salmefamol } \\
\text { Isoprenaline } \\
\text { Salmefamol } \\
\text { Isoprenaline } \\
\text { Salmefamol } \\
\text { Isoprenaline } \\
\text { Salmefamol } \\
\text { Isoprenaline } \\
\text { Salmefamol } \\
\text { Isoprenaline } \\
\text { Salmefamol } \\
\text { Isoprenaline }\end{array}$ & $\begin{array}{l}2 \cdot 8 \\
2 \cdot 8 \\
2 \cdot 9 \\
2 \cdot 9 \\
2 \cdot 9 \\
2 \cdot 9 \\
2 \cdot 6 \\
2 \cdot 6 \\
4 \cdot 0 \\
4 \cdot 0 \\
3 \cdot 0 \\
3 \cdot 0 \\
4 \cdot 2 \\
4 \cdot 2 \\
3 \cdot 2 \\
3 \cdot 2\end{array}$ & $\begin{array}{l}0.55 \\
0.55 \\
1.9 \\
1.75 \\
0.3 \\
0.3 \\
1.05 \\
0.9 \\
2.05 \\
2.4 \\
1.15 \\
1.25 \\
1.65 \\
1.6 \\
1.5 \\
1.45\end{array}$ & $\begin{array}{l}0.65 \\
0.95 \\
2.1 \\
2.2 \\
0.5 \\
0.4 \\
1.35 \\
1.8 \\
2.15 \\
2.8 \\
1.25 \\
1.55 \\
1.8 \\
2.0 \\
1.8 \\
1.65\end{array}$ & $\begin{array}{l}0.85 \\
1.1 \\
2.25 \\
2.25 \\
0.55 \\
0.45 \\
1.45 \\
1.9 \\
2.2 \\
2.9 \\
1.6 \\
1.7 \\
2.0 \\
2.2 \\
1.8 \\
1.7\end{array}$ & $\begin{array}{l}1.05 \\
1 \cdot 3 \\
2 \cdot 3 \\
2 \cdot 25 \\
0.65 \\
0.55 \\
2.0 \\
1.9 \\
2 \cdot 2 \\
3.05 \\
1.45 \\
1.9 \\
2.1 \\
2.2 \\
1.6 \\
1.8\end{array}$ & $\begin{array}{l}1 \cdot 0 \\
1 \cdot 3 \\
2 \cdot 3 \\
2 \cdot 15 \\
0 \cdot 6 \\
0 \cdot 65 \\
2 \cdot 15 \\
2 \cdot 0 \\
2 \cdot 3 \\
3 \cdot 1 \\
1 \cdot 6 \\
1 \cdot 9 \\
2 \cdot 25 \\
2 \cdot 2 \\
1 \cdot 75 \\
1 \cdot 75\end{array}$ \\
\hline
\end{tabular}


Table III gives the results for eight patients, and it can be seen that all satisfy the desired criteria. Figure 2 shows the mean results plotted

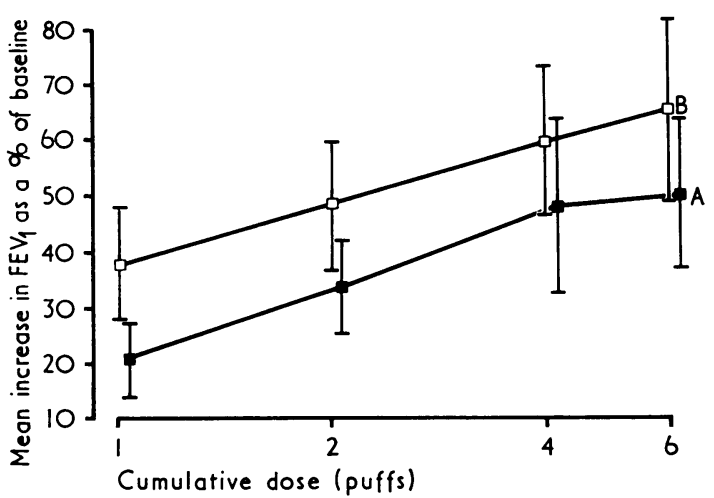

FIG. 2. Comparison of salmefamol $(A)$ and isoprenaline (B), 8 patients (mean $\pm 1 S E$ ).

for these patients as a log dose-response curve with the cumulative dose in puffs. Isoprenaline appears more active than salmefamol (using the paired $t$ test $\mathrm{P}=0.02$ for four puffs, and 0.05 for six puffs). Table I shows that one puff of isoprenaline contained $0.38 \mu \mathrm{M}$ whereas one puff of salmefamol contained $0.15 \mu \mathrm{M}$ per puff, or less than one-half of one puff of isoprenaline. Figure 3 shows the results plotted with the cumulative dose expressed in micromoles, and the drugs can be seen to be equipotent.

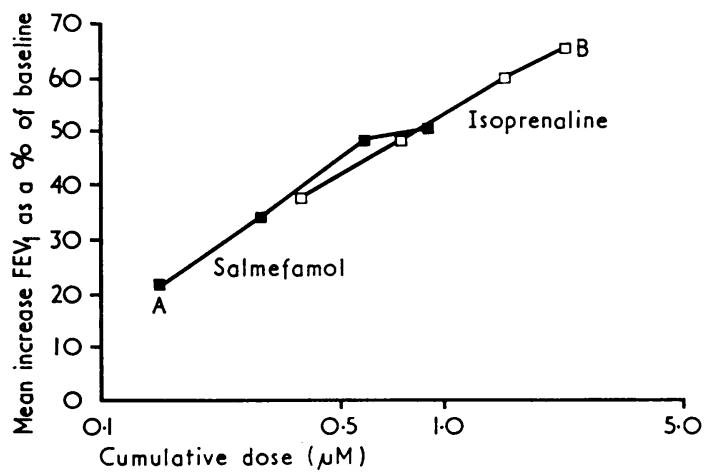

FIG. 3. Comparison of salmefamol $(A)$ and isoprenaline (B), 8 patients (dose in $\mu M$ ).

STUDY 3: RIMITEROL $v$ ISOPRENALINE Table IV gives the individual results for the eight patients. Table I shows that one puff of rimiterol contained
T A B L E I V

DETAILS OF PATIENTS AND THEIR FEV ${ }_{1}$ RESULTS IN STUDY 3

\begin{tabular}{|c|c|c|c|c|c|c|c|}
\hline \multirow{2}{*}{ Patient } & \multirow{2}{*}{ Drug } & \multicolumn{6}{|c|}{$\mathrm{FEV}_{1}$ (1.) } \\
\hline & & Predicted & Baseline & $\stackrel{1}{\text { Puff }}$ & $\stackrel{2}{\text { Puffs }}$ & $\begin{array}{c}4 \\
\text { Puffs }\end{array}$ & $\begin{array}{c}6 \\
\text { Puffs }\end{array}$ \\
\hline $\begin{array}{l}\text { C.F. } \\
\text { G.G. } \\
\text { J.S. } \\
\text { A.P. } \\
\text { R.M. } \\
\text { B.A. } \\
\text { B.P. } \\
\text { A.M. }\end{array}$ & $\begin{array}{l}\text { Rimiterol } \\
\text { Isoprenaline } \\
\text { Rimiterol } \\
\text { Isoprenaline } \\
\text { Rimiterol } \\
\text { Isoprenaline } \\
\text { Rimiterol } \\
\text { Isoprenaline } \\
\text { Rimiterol } \\
\text { Isoprenaline } \\
\text { Rimiterol } \\
\text { Isoprenaline } \\
\text { Rimiterol } \\
\text { Isoprenaline } \\
\text { Rimiterol } \\
\text { Isoprenaline }\end{array}$ & $\begin{array}{l}4 \cdot 35 \\
4 \cdot 35 \\
2 \cdot 75 \\
2 \cdot 75 \\
4 \cdot 0 \\
4 \cdot 0 \\
2 \cdot 4 \\
2 \cdot 4 \\
3 \cdot 2 \\
3 \cdot 2 \\
2 \cdot 6 \\
2 \cdot 6 \\
2 \cdot 5 \\
2 \cdot 5 \\
3 \cdot 1 \\
3 \cdot 1\end{array}$ & $\begin{array}{l}2 \cdot 0 \\
2 \cdot 2 \\
0 \cdot 45 \\
0 \cdot 5 \\
1.95 \\
2 \cdot 0 \\
1 \cdot 45 \\
1 \cdot 35 \\
1 \cdot 3 \\
1 \cdot 25 \\
1 \cdot 0 \\
1 \cdot 1 \\
0.9 \\
0 \cdot 75 \\
2 \cdot 0 \\
1 \cdot 95\end{array}$ & $\begin{array}{l}2.65 \\
2.7 \\
0.65 \\
1.15 \\
2.65 \\
3.0 \\
1.8 \\
1.6 \\
1.65 \\
1.45 \\
1.65 \\
1.6 \\
1.1 \\
0.95 \\
2.75 \\
2.45\end{array}$ & $\begin{array}{l}2.7 \\
3.05 \\
1.05 \\
1.3 \\
2.95 \\
3.5 \\
1.75 \\
1.65 \\
1.65 \\
1.5 \\
1.8 \\
2.0 \\
1 \cdot 15 \\
0.9 \\
2.9 \\
2.95\end{array}$ & $\begin{array}{l}2.8 \\
3.4 \\
1.05 \\
1.0 \\
3.4 \\
3.7 \\
1.7 \\
1.75 \\
1.75 \\
1.55 \\
1.9 \\
2.2 \\
1.25 \\
0.9 \\
2.9 \\
2.95\end{array}$ & $\begin{array}{l}3 \cdot 2 \\
3 \cdot 7 \\
0 \cdot 85 \\
0.95 \\
3 \cdot 65 \\
4 \cdot 1 \\
1 \cdot 8 \\
1 \cdot 8 \\
1 \cdot 75 \\
1 \cdot 6 \\
1.9 \\
2 \cdot 35 \\
1 \cdot 15 \\
1 \cdot 15 \\
3 \cdot 1 \\
3 \cdot 05\end{array}$ \\
\hline
\end{tabular}

$0.36 \mu \mathrm{M}$ and one puff of isoprenaline $0.38 \mu \mathrm{M}$. Figure 4 gives the average results for the patients plotted as a log dose-response curve with the cumulative dose in puffs. The drugs can be seen to be equipotent. Using a paired $t$ test there was no significant difference between them.

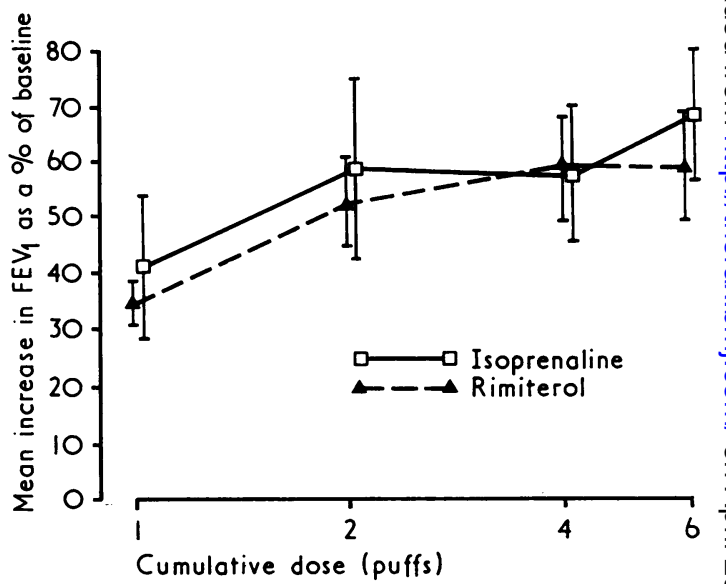

FIG. 4. Comparison of rimiterol and isoprenaline, 8 patients.

\section{DISCUSSION}

From these results we can conclude that all three drugs tested are active bronchodilators; that Th $1165 \mathrm{a}$ is at least equipotent with salbutamol; that salmefamol is equipotent with isoprenaline but that to achieve the same effect from one puff an aerosol should deliver at least $100 \mu \mathrm{g}$ of salmefamol $\stackrel{\square}{\square}$ per puff; and that rimiterol is equipotent with 
isoprenaline. We can also say that none of the drugs in the dosage used had any significant side effects. We consider that such conclusions are justified and possible to make from a small number of patients because of the manner in which the drugs were tested.

In the early stages of assessing a new bronchodilator drug it is obviously advantageous if a decision about dosage can be made quickly, using only a small number of patients (Long, 1967). Any method should be able to detect whether the drug is active or not, how its activity compares with other known bronchodilators, what the desirable therapeutic dose is, and whether there are any notable side effects. Our method achieves all these aims with the minimum of discomfort to the patient. It also overcomes several of the diffculties experienced by other workers.

Various methods can be used to measure the degree of airways obstruction present. These include peak flow, spirometry (measuring FEV at any desired time interval and FVC) or whole body plethysmography. The body plethysmograph is an expensive piece of apparatus which requires skilled operators. Hoffbrand, Hoffbrand, Hill, and Heaf (1966) found that the peak flow appeared to be a more sensitive index of changes in airways resistance after bronchodilator drugs than did measurements made with a portable bellows spirometer. However, spirometry is reproducible, simple to perform, less influenced by effort, and both the FEV 1 and FVC are obtained (Fairbairn, Fletcher, Tinker, and Wood, 1962). Minette (1970), in a study of 225 subjects, found that the reproducibility of $\mathrm{FEV}_{1}$ and $\mathrm{FEV}_{0 \cdot 75}$ was superior to the reproducibility of peak flow or forced expiratory flow. He found a great stability of baseline values and the most reliable way of expressing response to bronchodilator drugs was as the absolute increment in $\mathrm{FEV}_{1}\left(\triangle \mathrm{FEV} \mathrm{V}_{1}\right)$ or as the increment expressed as a percentage of the baseline $\left(\Delta \mathrm{FEV}_{1} \%\right)$. Other methods of plotting results, incorporating the predicted normal value, were less satisfactory. We have therefore used the $\mathrm{FEV}_{1}$ and expressed the results as $\Delta \mathrm{FEV}_{1}$ or $\Delta \mathrm{FEV}_{1} \%$.

Having decided on the method of measurement, there are other problems to be considered. Not only is there considerable variation between asthmatics, but Hume and Gandevia (1957) and Hume and Rhys Jones (1961) have shown that the response to a bronchodilator is related to the degree of bronchoconstriction present initially. Pain and Read (1963) showed that, even with the same baseline, responses to drugs could be different depending on whether patients were improving or deteriorating. These difficulties can be overcome by trials in large numbers of patients, but even then great care is needed in expressing the results (Racoveanu, Stănescu, Manicatide, and Stroescu, 1971).

Alliott et al. (1972) suggested that to keep a constant environment and to carry out the tests in as short a period as possible, studies should be done on inpatients. We agree with this, and minimized other variables by stopping all bronchodilator drugs for 10 hours before each study, using each patient as his own control, and ensuring that the baseline values were within $15 \%$ on the two study days. Furthermore, we knew before the studies that the patients were capable of responding to bronchodilator drugs, and that they had 'room' for improvement, since their $\mathrm{FEV}_{1} \mathrm{~s}$ were less than $70 \%$ of the predicted values. Freedman (1971), in a study of terbutaline, used 10 patients of whom five had an $F V_{1}$ greater than $65 \%$ of their predicted value. This makes the interpretation of results difficult, and Alliott et al. (1972) and Racoveanu et al. (1971) have attempted to overcome the problem by omitting some patients from analysis. We feel that it is better to pre-select the patients.

Minette (1971) claims that average results have considerable predictive value if they are applied to large enough numbers of patients. By adhering to our criteria we are able to make direct comparisons of the two drugs being tested, and draw valid conclusions from only a few patients.

In addition our method can offer extra information. Most of the trials described above indicate comparative efficiency but not the ideal therapeutic dose. Warrell et al. (1970), in their careful comparison of salbutamol and isoprenaline using the body plethysmograph, attempted to construct a $\log$ dose-response curve by giving increasing doses of each test drug. They had a series of four specially prepared aerosols chosen so that each dose was much larger than the dose which preceded it. This ensured that preceding doses made a relatively small contribution to the change in specific airways conductance observed after a particular dose. This produced good log doseresponse curves for each drug but involved the manufacturers in a considerable amount of work, since each aerosol has to be made up to rigid specifications. Our method is based on two assumptions: first, that once $\mathrm{FEV}_{1}$ measurements have 'levelled out' it is reasonable to give the next dose, and secondly that the time for this to occur (10 to 15 minutes) is so short that for dosage 
purposes the first puff can be considered still present and active when the second is given. In this way, given one, one, two, and two puffs in series, a cumulative dose has been given of one, two, four, and six puffs from the aerosol. Log dose-response curves can then be drawn and results compared within the same patient for each 'puff level', and even with as few as eight patients a paired $t$ test can achieve statistically significant results. Furthermore, when the data are plotted graphically, a fairly accurate estimate of the relative potency of the two drugs is obtained.

In our second study, isoprenaline appeared to be significantly better than salmefamol. When the data were replotted with the dose expressed in micromoles it could readily be seen that the drugs were equipotent (Fig. 3). For future testing we would therefore recommend that aerosols are made up in equimolar doses. Furthermore, it can be seen that four and six puffs of all the drugs had only slight advantages over two puffs, so that we would recommend two puffs as the therapeutic dose.

We are aware that 'a puff' is an inaccurate way of giving a drug, since a variable and small amount reaches the lungs (Paterson, Conolly, Davies, and Dollery, 1968). However, this is the way in which the drug will be used therapeutically, and we feel that with patients experienced in using aerosols there is considerable consistency in technique. There may well be variations between patients but since the comparisons are made within patients this does not matter. We also have evidence that patients studied three times a day for a week show very consistent responses to a bronchodilator given by aerosol (unpublished data).

In summary, we consider that by carefully selecting patients it is possible to give a rapid and quantitative assessment of a new bronchodilator drug. This should be of considerable use to clinicians and manufacturers in the early stages of drug evaluation.

We are grateful to the physicians at Brompton Hospital for allowing patients under their care to be studied. We are grateful to Dr. P. A. Knowlson,
Boehringer Ingelheim Ltd., for supplies of Th $1165 \mathrm{a}$; to Dr. D. M. Harris, Allen \& Hanbury's Ltd., for supplies of salbutamol; to Dr. C. H. Dash, Glaxo Laboratories Ltd., for salmefamol ; and to Dr. H. E. Lewis, Minnesota 3M Laboratories Ltd., for supplies of rimiterol.

G.M.S. is supported by a grant from the Medical Research Council.

\section{REFERENCES}

Alliott, R. J., Lang, B. D., Rawson, D. R. W., and Leckie, W. J. H. (1972). Effects of salbutamol and isoprenaline phenylephrine in reversible airways obstruction. Brit. med. J., 1, 539.

Fairbairn, A. S., Fletcher, C. M., Tinker, C. M., and Wood. C. H. (1962). A comparison of spirometric and peak expiratory flow measurements in men with and without chronic bronchitis. Thorax, 17, 168.

Freedman, B. J. (1971). Trial of new bronchodilator, terbutaline, in asthma. Brit. med.J., 1, 633.

Hoff brand, B. I., Hoffbrand, M. I., Hill, I. D., and Heaf, P. J. D. (1966). Trial of bronchodilator drugs given by metered aerosol with a comparison of two bedside methods of estimating airway resistance. Brit. med. J. $1,1014$.

Hume, K. M., and Gandevia, B. (1957). Forced expiratory volume before and after isoprenaline. Thorax, 12, 276.

- , and Rhys Jones, E. (1961). The response to bronchodilators in intrinsic asthma. Quart. J. Med., 30, 189.

Long, D. A. (1967). Clinical trials: a report to the Association of the British Pharmaceutical Industry. The Association of the British Pharmaceutical Industry, London.

Minette, A. (1970). Spirometric study of the bronchodilating effects of hydroxyphenylorciprenaline ( $\mathrm{Th}$ $1165 \mathrm{a}$ ) in various forms in a group of 124 coalminers suffering from bronchospasm. Respiration, 27, 276.

- (1971). Ventilatory results and side-effects of salbutamol given by different routes in coalminers with reversible broncho-obstruction. Postgrad. med. J., 47, Suppl. p. 55.

Pain, M. C. F., and Read, J. (1963). Patterns of response to bronchodilator in young patients with asthma. Aust. Ann. Med., 12, 216.

Paterson, J. W., Conolly, M. E., Davies, D. S., and Dollery, C. T. (1968). Isoprenaline resistance and the use of pressurised aerosols in asthma. Lancet, 2, 426.

Racoveanu, C., Stănescu, D. C., Manicatide, M., and Strcescu, V. (1971). The bronchodilator effects of orciprenaline and salbutamol. A double-blind study. Postgrad. med. J., 47, Suppl. p. 83.

Warrell, D. A., Robertson, D. G., Newton Howes, J., Conolly, M. E., Paterson, J. W., Beilin, L. J., and Dollery, C. T. (1970). Comparison of cardiorespiratory effects of isoprenaline and salbutamol in patients with bronchial asthma. Brit. med.J., 1, 65. 